\title{
THE STRUGGLE OVER THE FORM OF THE POLITICAL SYSTEM OF THE KARACHAY-CIRCASSIAN REPUBLIC AMONG THE RULING ELITES
}

\author{
by Tadeusz Bodio, Przemysław J. Sieradzan
}

\section{INTRODUCTION}

Karachay-Circassia, is very small both in the territorial and demographic aspect and is widely considered as one of the most politically unstable state-subjects of the Russian Federation. This instability is implied by a combination of many factors occurring against a relatively stable historical and cultural background. This background consists of: multiethnicity, colonization and sovietization, deportations, migrations, ethnic segmentation of the society, ethno-clanishness, ethnic and territorial conflicts and the geopolitical situation. The latter has often decomposed the natural development of nation-creating and state-creating processes. Moreover, it has also been the main cause of numerous tragedies of the local populace which sometimes has put its very biological existence under threat.

The factors mentioned above created a kind of "Transformation Loop Factor". At the same time, this loop tightens up, placing the question about the future of the republic on the agenda. There are many premises indicating that its future is not obvious: the republic may not survive in its present political structure, or even break up into two separate parts. In this regard, 
one should pay attention to the exceptional activity of the Circassians who make use of the Sochi Winter Olympic Games to mobilize the international community for the sake of support of their claims. The Abazins, the Nogay, and the Cossacks also demand a far-reaching autonomy.

In fact, the actions taken by the Moscow elites just "extinguish the fire" and help maintain the status quo in the republic. They do not solve systemic problems, thus unveiling the federal state (or, actually, "ethno-federal" state) weaknesses. The specific trajectory of this model - from decentralization in the $1990^{\text {s }}$, through centralization in the first half of the first decade of the $21^{\text {st }}$ century, together with the corrections implemented within the model as of 2012 - proves that this model does not fulfill its functions properly. However, one must admit that social and political processes in Karachay-Circassia are so peculiar that they hardly fit into the existing schemes of theoretical research in the field of transitology'.

Karachay-Circassia is a case of a subject-state of the Russian Federation which brings new threads and problems that require theoretical considerations related to the process of the creation of the theory of post-totalitarian transformation.

The opinions stating that the dissolution of Karachay-Circassia can start the process of the separation of North Caucasus form Russia, and possibly the disembratio of the whole federal state, are becoming more and more widespread. Accusations against Circassian organizations regarding their cooperation with Western intelligence agencies in the implementation of the so-called "Great Circassia project" are increasingly

1 In this extent we share the views of J. Highley and J. Pakulski, according to whom elites play the key role in the post-totalitarian transformation, D. Rustow, who pointed out the national consolidation as a condition of democratic transformation, and A. Melvil, who tried to combine the structural and procedural attempt in the analyse of federal state and its subjects. See: J. Higley, J. Pakulski, Elite Theory and Research in Poscommunist Societies, [in:] J. Frentzel, J. Wasilewski, The Second Generation of Democratic Elites in Central and Eastern Europoe, Warsaw 2000, p. 38; D. Rustow, Transition to Democracy: Toward a Comparative Model, “Comparative Politics” 1970, Vol. 2, April; A.Y. Melvil, Opyt teoretiko-metodologičeskogo sinteza strukturnogo i procedurnogo podchodov $k$ demokratičeskim tranzitam, "Polis" 1998, No. 2. The transitologic models and their use for the research of the transformation of elites in Russia are described by J. Ćwiek-Karpowicz in his paper Rosyjska elita władzy centralnej w latach 2000-2008, Warszawa 2011. 
popular. The Circassian secession alone may result in conflicts with the Balkars, the Ossetians, the Russians, and the Cossacks. The Russians, in a letter to president Dmitri Medvedev, even demanded a change of the name of the state, since the current name falsely suggests that the state belongs only to two nations ${ }^{2}$

The history of the republic provides evidence that the areas with their own national symbols, budget, and elites with their post-tribal connections generate ethnocracy ${ }^{3}$ and separatist tendencies. They become a kind of "micro-states". Their organization model fosters the polarization of the local elites on the basis of national, ethnic, and clan origin.

The basic symptom of the "transformation loop" of Karachay-Circassia is a lack of an authentic compromise among ethnic communities in the field of social and political order ${ }^{4}$. An attempt to work out this kind of compromise with the elites (with their own specific mentality, values and standards of behavior) took place in 1996 and finished with the development of a kind of a "constitution pact" of the elites. That compromise turned out to be short-lived and the republic as early as in 1999 was on the brink of civil war.

The power system is the prime conflict-generating link within the transformation chain: it's corrupt, inefficient, and inadequate to the ethnopolitical reality ${ }^{5}$. In practice, it results in various forms of pathology, manifested in the anarchization of the state and the ethnic elites, ethnocracy, separatism, criminalization of politics, and terrorist acts.

2 See Russkije žitieli Karačajevo-Čerkessii obratilis k Dmitriju Medvedevu, http://www. apn.ru/news/.

3 The mechanisms of formation of the ruling elites on the basis of "post-tribal bonds" (including "territorial exclusivism" and "ethno-territorial affiliation" are explained by R. Bäcker in his paper Podstawowe kategorie polityczne autorytaryzmu, [in:] Przywództwo, elity i transformacje, op.cit., p. 67 and later.

4 We got the inspirations for the "coil method" from P. Grochmalski.

5 The precise informations about the "coil method" and its mechanism are described by P. Grochmalski in his paper about the transitions in Central Asia. See. P. Grochmalski, Autorytaryzm centralnoazjatycki a kwestia transformacji systemowej - próba poszukiwania modelu metodologicznego, [in:] Przywództwo, Elity i transformacje w krajach WNP, ed. T. Bodio, Warszawa 507 and next. 
In this article we will approach the main problems of the transformation of the system of the republic, mainly related to the changes occurring within the structure of the ruling elite ${ }^{6}$. The genesis of these changes traces its roots to the history of the period of the Russian conquest. The mistakes of that period substantially imply the multiethnic situation of KarachayCircassia.

\section{THE CONQUEST AND ITS CONSEQUENCES FOR THE TRADITIONAL RULING ELITES}

The period of the Russian conquest, and especially the so-called Adyghe-Russian War which begun in 1763, left a heavy stigma on the Karachay-Circassian elites. The war lasted for over a century and proceeded both on dry land and at sea. In the year 1774, the Russians conquered Eastern Circassia and annexed its territories to the Empire ${ }^{7}$.

The war in Western Circassia was extremely long ant its intensity kept changing. Its pace was accelerated after the signing of the Treaty of Adrianople in $1829^{8}$, by virtue of which Turkey recognized the annexation of the Caucasus by the Russians.

The Adyghe-Russian War fostered the consolidation of the Circassian political and military elites. In June 1861 their leaders formed an "extraordinary alliance" and created Mejlis (Supreme Assembly of the Free Circassians). It was a permanent organ of power, endowed with legislative and executive powers. By its decision, the Circassian territories have been divided into counties ruled by local elites: representatives of the elders, the clergy and the Muslim judges 9 .

\footnotetext{
6 Those problems will be described more verbosely in a monography, which is being prepared by the authors.

7 See Russko-Čerkieskaâ vojna 1763-1864 gg. i jejo posledstviâ, http://circassiastate. blogspot.com/2011/04/1763-1864.html

8 More detailed information about the attitude of Circassians towards the Treaty of Adrianople: M. Blijev, Čerkesâ $i$ Čerkiesy. Kratkij očerk isstorii, Moskva 2011, p. 41 and later.

${ }^{9}$ See S. Chodko, Čerkiesskij Medžlis, http://www.circassiaonline.org/culture/ history/161-cherkesskij medzhlis.htm
} 
The Mejlis leaders both improved the administration system of the Circassian territories and showed diplomatic activity. According to historians, the creation of Mejlis was the Cirsassians' first attempt to organize their own centralized state and consolidate their elites, representing their own sub-ethnic groups ${ }^{10}$.

The fight for Western Circassia lasted until May 21 ${ }^{\text {st }}, 1864$. That day the last resistance point, Krasnaya Polyana not far from Sochi, fell. The Circassians faced an alternative: acknowledge the Imperial Russia supremacy or suffer displacement to the Osman Empire and other countries. The deportations, which started during the war, accelerated after the Circassian defeat and lasted until the end of the $19^{\text {th }}$ century. The traditional political elites were deported and repressed first. Contemporary historians still argue about the number of casualties of the war. Some sources claim that over $20 \%$ of Circassians were killed during the war, and that the Circassians lost $90 \%$ of their territories and over $90 \%$ of the population ${ }^{11}$.

Out of 1,5 million displaced Circassians, only 0,5 million got to the shores of Turkey. A very small number was displaced to the Kuban lowlands. According to Russian historians, this data is overestimated. They stress that in the Caucasus regular warfare took place. Moreover, they question the mass and planned nature of the killings ${ }^{12}$.

The results of the war were catastrophic for the Circassians. They used to dominate in the political, military, and demographic aspect in the Northern Caucasus, but in the first years of the Soviet Union existence they were only a small ethnic group, smaller still during the times of the dissolution of the USSR. Currently, they are a "title nation" of Karachay-

10 Ibidem, p. 104.

11 This question is very controversial among historians. The diversity of the data given by historians is extremely high. See. Russko-Čerkiesskâ̂ vojna, op.cit.; T.Ch. Kumykov, Problemy Kavkazskoj vojny i vyselenije čerkiesov v priediely Osmanskoj imperii (20-70 gg. XX v.) Sbornik archivalnych dokumentov, Nalčik 2001 and other works.

12 Quite a representative review of opinions of the Western, Circassian, and Russian historian are provided in the article by professor M. Czuch: Genocid Čerkiesov - istoria $\hat{a}$ probliemy, hronika sobytej, naučnyje zaklučenije, http://www.parlament.ge/files /1544_32742_447460_genocidi-ru.pdf; M. Blijev, Čerkesâ $i$ Čerkiesy. Kratkij očerk isstorii, Moskva 2011; M. Budaj, "Velikaâ Čerkessiâ" - poslednij sag k razvalu Rossii, Karacaevsk 2011. 
Circassia (56,4 thousand, 11,9\%) - third from the point of view of demographic potential after the Karachay (194 thousand, 41\%) and the Russians (150 thousand, $31,6 \%)^{13}$.

The war left a heavy stigma on future generations and the relations of their elites with the Kremlin. Currently, the Circassian elites claim that the Russian expansion aim was to biologically exterminate the nation and abolish the state existence. They demand the Kremlin's acknowledgement of their nation's genocide, rehabilitation, and representation in republican institutions based on the principle of parity, as well as a right to establish their own form of political entity within the federation. It is noteworthy that Georgia is the first country where the parliament has recognized the genocide of the Circassians (May 20 th, 2012 ).

The history of tiny Karachay, located in a strategically very important part of the Caucasus, is equally dramatic. According to some researchers, Karachay was a ethno-cultural entity that in the time of conquest was close to building its own model of state ${ }^{14}$. It was characterized by a peculiar political system with a number of counties subordinate to the Supreme Lord (Olij). The system of power was tribal and corporate. It reflected the feudal and hierarchical social structure of this political entity with some features of a state.

In June 1826 the authorities of Karachay had concluded a neutrality agreement with Russia. Although both sides accused each other of breaking the terms of the agreement, in the context of Russian conquest plans it was a tactical trick of the imperial officials. In 1826, the Russians sent a military expedition in order to annex Karachay to the Empire. On October $20^{\text {th }} 1826$ the Karachays were vanquished in the struggle with a several times more powerful enemy ${ }^{15}$. The Karachay leaders agreed to join the Empire. They were assured by the Russian side that they would be allowed to maintain their traditional legal and political order, based on adat and sharia norms, including the political system and the mechanisms of elite recruitment.

\footnotetext{
13 Data of 2010 .

14 See I.M. Miziev, Istoriâ Karačaevo-Balkarskogo Naroda z drevniejšych dniej do prisoedinieniâ k Rossii, Nalčik 1995 (part. VII).

15 Ibidem.
} 
At specific stages of their conquest of the Circassian and Karachay territories, the invaders used a flexible policy towards the local ruling elite. One of the elements of this policy was the successive implementation of the Russian plans of governance over the annexed territories. As a result, on the russified territories a two governance systems emerged: the central and the ethnic-local one. The former (administrative and military) was the responsibility of imperial officials, the latter meanwhile was traditional and (while being controlled by Russians) set tribal and all level regulations. In the second half of the XIX century, after several political and administrative reforms, the incorporation of the Kuban area and the Russian settlements, the traditional institutions among the elites were successively superseded from Circassian and Karachay life.

\section{THE PROCESS OF SOVIETIZATION OF THE RULING ELITES}

After the end of the civil war, on November $17^{\text {th }} 1920$, during the convention of the nationalities of the Terski Area (at which Joseph Stalin was present) a decision to create the Mountain Autonomous Soviet Socialist Republic was made. This republic consisted of six areas, including the Karachay Area. This decision was approved on January $20^{\text {th }} 1921$ by the All-Union Executive Committee ${ }^{16}$.

During further administrative and territorial reforms of the region, a project of the creation of a common political and administrative entity for Karachay and Circassians was considered. The works over this project were full of bitter conflicts and tensions among the ruling elites of that time in the areas considering the distribution of power, territories and a demarcation of the area borders ${ }^{17}$.

On January $12^{\text {th }} 1922$ a decree was signed. It authorized the creation of an autonomous unit within the North-Caucasus State of the Russian

\footnotetext{
16 See Očerki po istorii Karačejevo-Čerkesii. Sovietskij period, Čerkiesk 1972, t. 2, p. 98.

17 A.G. Kažarpov, Alijev U.D. i Kabardyno-Karačaevskije etnoterytorialnyje otnošeniâ $v$ načale 1920 gg., [in:] Vymysiel, op.cit., p. 286 and later.
} 
Federal Soviet Socialist Republic, with five areas and the capital in Batalpashinsk ${ }^{18}$. According to the decree, the autonomy authorities were to be formed in accordance with the rule of parity as regards the representation of national and ethnic groups. In practice, it turned out that the parity became (and remains until today) a source of ethno-political conflicts.

The conflicts that arouse around the composition of the representative bodies reveal that the decision to create a polyethnic area, in which Karachays and Circassians were deemed native, did not take the local cultural and confessional specificities into consideration and neither considered the elites' expectations and aspirations. Those conflicts generated separatist tendencies. As a result, on April 26 ${ }^{\text {th }} 1926$ the All-Union Executive Committee decided to abolish the Karachay-Circassian Autonomous Area and create the Karachay Autonomous Area and the Circassian National Area. By virtue of that decision, signed by Mikhail Kalinin on April $30^{\text {th }}$ 1928, the legal status of the latter had been equaled with that of the Karachay Autonomous Area.

Archive data reveal that in the years 1922-1943 the borders were alternated many times. It is the same case with the internal administrative and territorial organization of the Karachay-Circassian Autonomous Area and its two separate regions: Karachay and Circassian ${ }^{19}$. It was as a result of an elite conflict mentioned above, connected with the delimitation of borders and their internal administrative and territorial division on conditions of the noticeable lack of arable land and pastures. This conflict had an internal and an external aspect. The former appeared during the controversies between the Karachay representatives with their neighbours, the Kabarday and the Balkar, already at the stage of the drafting of the region's division and delimitation of the borders on the basis of ethnic criteria. The fact that during the first month after the creation of the Karachay-Circassian

18 Materialy k putewoditelu po fondam GKU “Centr dokumentov", Čerkiesk 2009, p. 164 and later.

19 Materialy k putewoditelu, op.cit., pp. 167-169. 
Autonomous Area riots and fights took place (with mortal casualties) is a testimony of the scale of the conflict ${ }^{20}$.

The border controversies did not cease in the following years. The relations between ethnic elites within the same areas were also sources of conflicts. They concerned both the distribution of power, as well as the administrative and territorial division and the question of the creation of administrative and territorial enclaves ${ }^{21}$.

The first stage of nomenclature creation in the autonomy covered the period of the New Economic Policy and was carried out under the slogan of "the return of alien elements to the power structures" 22. It influenced the pragmatics of the style of the ruling elites' activity where the modernization elements interweaved with the local, traditional life model and a network of informal ethnic and clan connections. That style generated ethnocracy. According to a member of the former Karachay elite, A.U. Aliev: "the ethnic collisions on the elite level were in the first place" in the Karachay-Circassian Autonomous Area ${ }^{23}$.

The second stage, which began in 1928, was characterized by a decadelasting ethnic cleansing 24 . The aim was to eliminate the people formerly promoted by the nomenclature and discriminate that part of the (small in numbers) intelligentsia which was accused of nationalism. Along with cadre purges, a struggle against Muslim clergy was intensified. The clergy

20 For more details: I.A. Džahazaeva, Processy administrativno-teritorialnogo razmeževanija v Karačaje v 1920-130 gg, "Naučno-teoretičeskij Žurnal, Naučne Probliemy Gumanitarnych Issledovanij” 2011, issue 6, p. 34.

21 For example, in 1925 on the basis of en ethnic criteria the Nogay-Abazin Area was created, which was later, in April 1926, included in Circassian National Area. The administrative and territorial system of the Cossack territories undergone similar changes. See: Materialy k putevoditelu, op.cit.., pp. 167-169. The consequences of permanent reorganizations have manifested themselves recently - the ethnic elites supported the territorial model of the republic based on the distinctly separated ethnic regions. For more details: I.A. Džahazaeva, Processy, op.cit., p. 34.

22 See Z.I. Adžijeva, Formirovanije nacionalnoj biurokratii v avtonomnych obrazovaniâch RSFSR v piervyje diesâtiletiâ Sovietskoj Vlasti: na materialach Karačajevo-Čerkesii (1920-1941 gg.), Avtoriefierat kandidatskoj dissertacii, Karačajevsk 2009.

23 Cited after I.A. Džahazaeva, Processy, op.cit., p. 36.

24 Z.I. Adžijeva, Formirovanije nacionalnoj biurokrati, op.cit. 
was taxed. Moreover, mosques and schools were closed ${ }^{25}$. The repression wave against the clergy reached its apogee in the second half of $1930^{\text {s. }}$.

The cultural revolution, the industrialization and the collectivization strongly influenced the formation of nomenclature in those areas and regions. The collectivization combined with "militant atheism" left a particularly strong stigma in the structures of power and their personal composition ${ }^{26}$. On the one hand, it mobilized the party apparatus through agitation and cadre purges while developing the basic party structures in rural regions. On the other, it decomposed the traditional lifestyle and eliminated the remains of the "old" ruling elites (including the deportation of their members in 1934 to the desert regions of the Uzbek Soviet Socialist Republic).

1934 was a tragic year in the history of the Karachays who were then accused of collaboration with German occupants. As a result of those accusations, on October $12^{\text {th }} 1943$, the Presidium of the Supreme Council of USSR issued a decree on the abolition of the Karachay Autonomous Area and the displacement of Karachay people into other regions of USSR $^{27}$. Until the end of March 1944, 70 thousand Karachays were displaced into Kazakh and Kyrgyz Soviet Socialist Republics. It is estimated that about 43 thousands of Karachay people (including 22 thousand children) died due to repressions, epidemics, and starvation ${ }^{28}$. In parallel

25 Ibidem, p. 18 and later.

26 Cf. I. Teekev, Agrarnaâ politika i kolektivizaciâ w Karačaje, Avtorieferat kandidackoj dissertacii, Karačajevsk 2010.

27 See Prezidium Verchovnogo Sovieta SSSR. Ukaz ot 12 oktâbriâ a 1943 goda o likvidacii Karačajevskiej Avtonomnoj Oblasti i ob. administrativnom ustrojstvie jejo territorii, http://tehnorma.ru/doc_ussrperiod/textussr/ussr_4462.htm.

28 Data from: V. Sznirelman, Peredel subdy (Kabardyno-Balkariâ i KaračajevoČerkesiâ), [in:] Vymysiel, op.cit., p. 82.The Karachay deportations were precisely described in the scientific literaturę. See: Chanâ Siro, Sekretnyj doklad N.S. Chruščeva $i$ vosstanovlenije avtonomnych territorij v 1957 g., "Akta Slavica Japonica", Vol. 22; A.D. Kučujev, Karačaevskaâ avtonomnaâ oblast w gody Vielikoj Očestvennoj vojny, Moskva 2000; E.A. Adžijeva, Deportaciâ narodov severnogo Kavkaza w gody vielikoj otčestvennoj vojny: pričiny i psledstviâ, Autorieferat kand. dissertacii, Piatigorsk 2001; R.S. Tebuev, Deportaciâ karačejevcev, Čerkievsk 1998 and other. 
with the "forever and with no right to return" displacement, actions to wipe the Karachay off the USSR citizens' memory had been taken.

On February $25^{\text {th }} 1956$, during the XX Congress of the Communist Party of USSR, Nikita Khrushchev in his secret lecture about the personality cult and its consequences pointed out the deportations as an example of Stalin's criminal activities. That speech started the process of the rehabilitation of the nation and its elites. The Karachay displacement was recognized as an unlawful act, so was the decree on the abolishment of the Karachay Autonomous Area ${ }^{29}$. On January $9^{\text {th }} 1957$, the Presidium of the Supreme Soviet of USSR issued a decree on the creation of the autonomy of the displaced nations within Russian Federal Soviet Socialist Republic, including the Karachay-Circassian Autonomous Area ${ }^{30}$.

The conditions of the rehabilitation were not entirely fulfilled. From the current point of view, it can be determined that the return to the territorial and administrative system from before 1943 would be the optimal and the least conflict-generating variant. The modern-day generations of the Karachay and their political elites still suffer the consequences of the deportations. From 1960 till the beginning of Mikhail Gorbachev's perestroika, the Karachay were discriminated as regards the cadre policy. Their access to security organs was limited. It was harder for them to join the Party. The highest posts were taken by Russians who often did not know the local specificities.

29 See Postanovlenije CK KPSS ot 24 noâbriâ 1956 g. O vosstanovleniû nacjonalnoj avtonomii Kalmyckogo, Karačajevskogo, Balkarskogo Čečenskogo i Ingušyckogo narodov, http://www.minnacri.ru/index.php.

30 See Prezydium Verchovnogo Sovieta SSSR. Ukaz ot 9 ânvariâ 1957 goda O preobra-

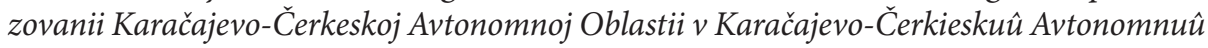
Oblast, http://tehnorma.ru. 


\section{THE USSR DISSOLUTION AND THE LIMITED SOVEREIGNTY ETHNICIZATION}

The political breakthrough of 1989-1990 in the union state fostered the radicalization of social emotions and spontaneous formation of national movements and organizations within the autonomy. Firstly, their common denominator was "settling accounts with the history of colonization and sovietization", the demand of full rehabilitation of the persecuted nationalities and ethnic groups and the acknowledgement of their right to self-determination.

The Karachay elites were especially active. In the spring of 1989 they organized the "Jamaat" (the Community) movement which aimed to reestablish the autonomy inside its 1943 borders. From their point of view, such an act would be one of historical justice ${ }^{31}$. The leaders of this movement initiated an extraordinary conference of the Karachay deputies on November $17^{\text {th }} 1991$ which approved The Declaration of State Sovereignty of The Karachay Republic ${ }^{32}$, while on November $3^{\text {rd }}$ the Deputies Congress in Cherkessk, under pressure from demonstrations, adopted a decision to divide the area into two separate autonomous entities. As a result, Boris Yeltsin submitted on February $5^{\text {th }}$ a draft law concerning the creation of two separate autonomies within the Russian Federal Soviet Socialist Republic ${ }^{33}$.

The current political atmosphere fostered the Karachay separatism. On November $14^{\text {th }} 1989$, the Supreme Soviet of USSR accepted the declaration in which the acts of repression and deportations of nations (including The Karachays) were defined as unlawful and criminal ${ }^{34}$ activities. On

31 The movement was a part of Karachay-Balkar "Tijre" movement, which supported creating the Turkish-speaking republic in Northern Caucasus within the Russian Federation See S. Čerwonnaâ, Tiurskij mir Severnogo Kavkaza: etničeskije vyzovy i tupiki federalnoj politiki, http://www.kazanfed.ru/publications/kazanf...alist/n1/stat4/.

32 See T. Litvinova, Političeskije instituty na Severnom Kavkazie v kontekstie razvitiâ rossyjskoj gosudarstviennostii, Saarbrucken 2011, p. 35.

33 See S.M. Čerwonnaâ, Tiurskij mir, op.cit..; eadem, Etničeskij faktor, op.cit.

34 See Deklaraciâ VS SSSR ot 14.11.1989 o priznanii niezakonnymi i priestupnymi represivnych aktov protiv narodov, podviergšichsâ nasilstviennomu pereseleniû, i obezpie- 
April 26 $6^{\text {th }} 1991$ another act of rehabilitation of repressed nations was issued $^{35}$. The document provided for a full rehabilitation of all the nations, ethnic groups and Cossack communities. Its paragraphs 2 . and 6. affirmed their right to reactivate ethno-territorial entities which existed up until the times of repressions and deportations.

The separatist aspirations of the Karachay elites triggered a chain reaction: a parade of sovereignty of the biggest nations and ethnic groups in this little area. The Cossacks who were afraid of including their area into the Karachay, formed in 1990 a "Cossack Society" aimed to consolidate their communities in the territory of the Karachay-Circassia Republic. Their activity soon brought effects. On August $10^{\text {th }} 1991$, the Batalpashinsk Cossack Republic was formed. Nine days later two regions populated mostly by Cossacks were united and Zelenochusk-Urypsk Cossack Soviet Socialist Republic with the capital in Zelenochusk was created.

The "Adyge Khase" organization, created in 1989, was the main political platform of Circassian political activity. From the leaders point of view, the documents accepted by the highest authorities of the Russian Federal Soviet Socialist Republic affirming the Karachay right to autonomy automatically provided the Circassians with a right to create their own separate ethnic and territorial entity. That is why on October $24^{\text {th }} 1991$, in response to the Karachay decision, they convened a congress of Circassian deputies which supported the foundation of a Circassian Republic ${ }^{36}$. This initiative was supported by the leaders of the International Circassian Association, created in May 1991 in Nalchik.

The Abazins demanded the return of the lands which were taken away form them during the collectivization, as well as the re-delimitation of administrative borders and the cancellation of the annexation of their area

cenii ich prav, Verchovnyj Soviet SSSR, Deklaraciâ ot 14 noâbriâ 1989 goda, http://pravo. levonevsky.org.

35 See Rosijskâ Sovietskaâ Federativnaâ Socialističeskaâ Respublika. Zakon o Reabilitacii Represjonovanych Narodov, 26 apriela 1991 g, N 1107-I, http://www.businesspravo. ru; Postanovlenije ot 16 ijûlâ 1992 g. N 3321-I O reabilitacii Kazačestva, Vierchovnyj Soviet Rossijskoj Federacii, http://magnitka.ru/index/postanovlenije.

36 See K. Kazenin, “Tichyje” konflikty na Severnom Kavkazie. Adygeâ, KabardynoBalkaria, Karačajevo-Čerkiesja, Moskva 2009, pp. 123-124. 
by Circassians. In November 1991, they proclaimed the creation of their own republic. In the same year Nogay people who belonged to Birlik ("the Unity") organization also decided to form their own republic ${ }^{37}$.

The official authorities of the area considered the decisions described above illegal. On the session convened on November $30^{\text {th }}$ 1990, the deputies of the area approved an act of The Karachay-Circassian Socialist Republic proclamation. The new republic was meant to be a sovereign state within the Russian Federal Soviet Socialist Republic. The declaration got a positive response from the Supreme Council of the Russian Federal Soviet Socialist Republic which confirmed the new legal status of Karachay-Circassia on July $3^{\text {rd }}, 1991^{38}$.

Actions were taken by the authorities of the just-proclaimed republic in order to block the bill submitted by Boris Yeltsin in the Supreme Soviet of the Russian Federal Soviet Socialist Republic. They adopted a decision organizing a referendum regarding the political system of the republic: it was held on March $22^{\text {nd }} 1992$, in conditions of a very tense ethno-politic situation. It was attended by $75 \%$ of those eligible to vote, of which $78,6 \%$ voted against the division of the republic ${ }^{39}$. The referendum had determined to withdraw from the Supreme Soviet of USSR a draft law of the division of the republic into three different ethno-political entities. Later, on October $16^{\text {th }} 1992$, the name of The Karachay-Circassian Socialist Soviet Republic was changed to The Karachay-Cherkess Republic.

To sum up, the process of forming the new political model of The Karachay-Circassia revealed mistakes in national policy and the hidden conflicts among the ethnic elites of the period of the conquest and sovietization.

37 See T. Litvinova, Političeskije instituty, op.cit., p. 70.

38 Zakon RSFSR ot 0.3.07.1991 N 1537-1 O prieobrazovanii Karačajevo-Čerkieskoj Avtonomnoj Oblastii v Karačajo-Čerkieskuû Sovietskuû Socjalističeskuû Respubliku, "Leninskije znamâ" 1991, No. 121, http://www.bestpravo.ru/rossijskoje/jm-pravo/; por. Zakon 0 vniesienii izmienieij v statiû 2 Zakona RFSRR O prieobrazovanii Karačejevsko-Čerkieskoj

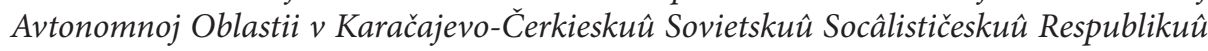
$w$ sostavie RFSRR, 22 dekabriâ $1992 \mathrm{~g}, \mathrm{~N}$ 4234-1.

39 See Ch. Ch. Kazakov, Integraciâ nacjonalno-kulturnych obščestvennych obiedinienij v regionalnû̂ političeskuû sistiemu (na primierie Karačajo-Čerkesii, Moskva 2011, p. 89; S.M. Čerwonnaâ, Tiurskij mir, op.cit. 
The multiethnicity and the division of power (according to the parity principle or proportionally to the ethnic structure of the area) were a kind of epicenter of those conflicts. The Circassian elites supported the parity principle, while the Karachay and Russian elites opted in favor of the proportional model.

The proclamation of The Karachay-Circassian Republic did not solve the severe problems of the nations and ethnic groups living in its territory. The nomenclature was conscious of threats to its positions in case of radical political changes in the Karachay-Circassia. It had shown the abilities necessary to adapt to the transformation requirements. It managed to gain profits from the market economy it implemented. A part of the nomenclature (depending on national identity) divided into centers of ethno-political power: centers which competed in an overt hidden form. After the creation of the republic, the process of the ethnicization of the elites and the politization of the ethnicity began to increase, starting to supersede the thinking in the categories of state, with benefit different kinds of ethnocracy. The latter opened the gates for institutionalization of the "second circuit" elites: the elites of ethnic and clan character which were equally influential, but remained outside the structures of power in Karachay-Circassia. The ethnicization of the political life, for many leaders of movements and organizations of national and ethnic elites, became a chance of promotion, a leap into joining the elites of the highest authorities of the state.

The issue of ethnicity was sometimes treated as a bargaining chip in the struggle for power. The ethnic elites on their mother territories were influential enough to block the decisions of central authorities. The described situation fostered pathologies, including the development of informal political connections and the criminalization of a part of the ruling elite.

\section{THE POLITICAL CRISIS OF 1999}

Vladimir Islamovich Khubiev was the first head of the Republic of Karachay-Circassia and held his office longer than anyone else so far. $\mathrm{He}$ remained the most important politician of the republic for 20 years, from 
1979 until the lost elections of 1999 . He owed his strong position to his "sixth sense" for the political situation changes and his loyalty to the rotating leaders of USSR and Russia. He was such an influential politician that the twenty years of his rule are referred to as "the Khubiev Era" 40.

Vladimir Khubiev was a staunch supporter of the model of harmonious cooperation between the republican and the federal political elites. He sustained that all of the important offices of the local self-government should be elective, and criticized the idea of central nomination of the officers. He opposed the idea of the division of the republic into Karachay and Circassia and criticized the parity principle. He was against the attempts to grant a privileged status to particular nationalities and the usage of the term "native" in regard to some groups of people, which would be the justification for special rights. He supported the equality of all nationalities and ethnic groups living in Karachay-Circassia ${ }^{41}$.

Vladimir Khubiev and the local elites' support for Boris Yeltsin's military action in Chechnya corroborated the federal government's belief that in case of crisis it could count on the loyalty of the authorities in Cherkessk ${ }^{42}$. One should remark, though, that during the period of Khubiev's moderate rule, nationalists' influence started to surge (firstly the Karachay, then mostly the Circassian and the Abazin).

Vladimir Khubiev overtly expressed his pro-Moscow orientation, his dislike for nationalism and criticism towards the separatist claims. He was, however, a nominated republican leader, not one elected in a popular vote.

The first presidential election in the history of the republic was appointed on April $25^{\text {th }} 1999^{43}$. It was widely thought that, thanks to the conciliatory policy of local authorities the relations between the Karachay, the Russians and thee Circassians were relatively peaceful and thus the electoral process would be undisturbed ${ }^{44}$. However, the opinions about the tranquility in the republic turned out to be illusive. The animosities

\footnotetext{
40 See Epoha Vladimira Hubieva, Čerkesk 2009.

41 See Hubiev Vladimir Islamovič, http://www.panorama.ru/bio/hubiev.shtml.

42 See Hubiev Vladimir Islamovič, http://www.niiss.ru/Publications/FedSob/SF/H/ hubiev.htm [15.01.2012].

43 See M. Vinogradov, Pomniki po "partii staroj vlasti”, "Russkaâ mysl”, 29.04.1999.

44 See T. Muzaev, Vybory pod akkompanement vzryvov, "Russkaâ mysl”, 13.05.1999.
} 
between the nations, hidden for decades, were revealed at the first possibility (i.e., the presidential election).

The chances of the main pretenders to win the election seemed equal. Among the most serious candidates were: the incumbent head of the Republic, Vladimir Khubiev (an ethnic Karachay, supported by Moscow), a retired general of the Russian army, former land army commander Vladimir Semenov (son of a Karachay man and a Russian woman) and the republican capital mayor, Stanislav Derev (Circassian) ${ }^{45}$.

Although Vladimir Khubiev was supported by the federal government, his chances to win shrank every week. The voters had the impression that the republican leader wanted to remain in power at any cost. His attempts to extend his mandate and limit the passive voting rights were found particularly repulsive $e^{46}$.

The election campaign was full of aggressive rhetoric and nationalist slogans. The atmosphere of political confrontation aroused the long-forgotten animosities: the Karachays and the Circassians consolidated around the candidates favorable to their own ethnic group.

The ethnicity, the importance of which for political life Vladimir Khubiev tried to minimize, became the most important criterion of social divisions in Karachay-Circassia. The political preferences of Russian voters gained the decisive importance because of the antagonism between the Karachays and the Circassians ${ }^{47}$.

In the period preceding the elections, Russian public opinion was shocked by an assassination attempt of the President of Supreme Court of Karachay-Circassia, Islam Burlakov. On April 10 ${ }^{\text {th }} 1999$, in Cherkessk an unknown offender threw a hand grenade at him. Islam Burlakov was seriously injured ${ }^{48}$. This shocking act of terror was the harbinger of the escalation of violence at the time of the election.

\footnotetext{
45 See M. Vinogradov, Karačaevo-Čerkiesiâ: Ty znaeš, vsë eščë budet!, "Russkaâ mysl”,, 18.03.1999.

46 Ibidem.

47 Ibidem.

48 S. Topol', V Čerkeske vzorvali glavu Verhovnogo Suda, “Kommersant”, 15.04.1999.
} 
The winner did not emerge during the first round of presidential elections. Contrary to the expectations, the mayor of Cherkessk, Stanislav Derev, achieved the best result: $40,1 \%$ of the votes. General Vladimir Semenov got only $17,9 \%$ of the votes ${ }^{49}$.

Vladimir Semenow could count on the Karachay voters, while Stanislav Derev was supported by the Circassians and the Abazins. The Russian votes were crucial ${ }^{50}$. After the first round of the election, the ethnic animosities surged. The candidates fuelled the nationalist sentiments. Stanislav Derev called Vladimir Semenov "second Shamil Basaev" and warned against his rule which would be tantamount to a Karachay dictatorship in which the rights of the Circassians, the Russians and other nationalities would be breached. The fact that nationalist leaders joined the campaign made the situation even worse ${ }^{51}$.

The second round of elections took place on May $16^{\text {th }} 1999$. Vladimir Semenov was supported by $75 \%$ of the voters, while the winner of the first round Stanislav Derev received $18,6 \%$ votes. Semenov's clear victory did not stabilize the situation, it inflamed the conflict ${ }^{52}$.The runner-up did not wait for the announcement of the official results. He called his supporters to launch a demonstration against "the bogus election". The Central Election Commission rejected the claims of Stanislav Derev ${ }^{53}$.

The Circassian nationalists dominated the protest. They made an ultimatum: if the results of the voting were declared legitimate, the Circassians would consider themselves "unable to live with the Karachays within the same republic". In different regions of the republic mass fights and riots between the Karachays, the Circassians and the Abazins took place $^{54}$.

\footnotetext{
49 N. Gritčin, Na post glavy Karačaevo - Čerkesii pretenduûut vodočnyj korol' i general, "Izwestiâ", 25.04.1999.

50 See S. Šermatova, Russkij faktor, "Moskovskie Novosti”, 25.04.1999.

51 T. Muzajev, Vybory glavy Karačaevo - Čerkesii..., op.cit.

52 D. Nikitin, Narodnaâ vojna èlit, “Obščaâ gazeta”, 13.05.1999.

53 T. Muzaev, Vybory glavy Karačaevo - Čerkesii..., op.cit.

54 Ibidem.
} 
More and more Circassians and Abazins supported the idea of secession and unification with the Stavropol Krai ${ }^{55}$. The ethnic tension reached its zenith. The Republic was on the brink of civil war ${ }^{56}$.

The federal government decided to intervene. Prime minister Sergey Stepashin called both conflicted candidates to begin immediate negotiations. After his meeting with Vladimir Semenov and Stanislav Derev, both candidates issued a statement, in which all the parties obliged themselves to endeavor to maintain "peace and unity in the republic" 57.

According to Sergey Stepashin "the situation had been frozen, but a solution still seems far away" 58 . This cautious statement turned out to be overly optimistic: the agreement was broken on the next day. Stanislav Derev demanded the cancellation of the election on the very first day after his return to Cherkessk; otherwise Circassia was to unilaterally proclaim its separateness ${ }^{59}$.

Sergey Stepashin decided to go to Karachay-Circassia personally. During his visit there, on 24 May 1999, he accepted the resignation of the incumbent president of the republic W. Khubijev, then made a decision to halt the announcement of the election results ${ }^{60}$.

The prime minister's decision did not solve the conflict. It was seen as a violation of the constitutional rights of the republic's population to decide over their own destiny ${ }^{61}$. Not only the Circassian supporters of Stanislav Derev protested against the prime minister's solution. The Karachays, who demanded to hand over power to Vladimir Semenov were also deeply unsatisfied. In June and early July of 1999, the social situation in the region temporarily calmed, but in the second half of July confrontational sentiments came back with redoubled force. The number of republic citizens

\footnotetext{
55 N. Gritčin, Û. Krutikov, Čerkesy i abazincy gotovy prisoedinit'sâ $k$ Stavropolû, "Izvestiâ", 18.05.1999.

56 See I. Sinâkevič, Karačaevo - Čerkesiâ na grani raskola, "Novye Izvestiâ", 18.05.1999.

57 Sinâkevič, Golubev dlâ mira, "Novye Izvestiâ", 19.05.1999.

58 Ibidem.

59 T. Muzaev, Vybory glavy Karačaevo - Čerkesii..., op.cit.

60 Ibidem.

61 S. Suhova, Karačaevo-Čerkesiâ pošla po “tret’emu puti”, “Segodnâ”, 25.05.1999.
} 
who participated in the demonstrations became larger and larger62. The ethnic-based acts of violence took place in the whole region. Many formerly politically and ethnically indifferent citizens discovered their identity ${ }^{63}$.

Vladimir Putin who became prime minister on August $9^{\text {th }} 1999$ considered finding a solution to the conflict in Karachay-Circassia as one of his major challenges. The conflict was far from settlement. On August $31^{\text {st }}$ 1999, Stanislav Derev announced the unilateral secession of the Circassian territories, which were now meant to become an autonomous territory within the Stavropol Krai ${ }^{64}$.

After a few rounds of fruitless negotiations, Vladimir Semenov swore the oath and thus started to act as head of Karachay-Circassia. The federal ruling elites reacted ambiguously to this unilateral act. Vladimir Putin decided that Vladimir Semenow started his tenure in accordance with the law, while some central administration officials questioned the election winner's legitimacy. The conflict in the republic was exacerbated again. Both sides organized demonstrations attended by thousands of citizens. Stanislav Derev demanded the incumbent republic leader's resignation. Public opinion was shaken by a series of arsons and bombings of Karachay cafés. The acts of violence seemed endless. On September $23^{\text {rd }} 1999$, a Federal Commission for the Karachay-Circassian Conflict Solution was founded. It was Vladimir Putin himself who became chairman of the committee. The Russian prime minister overtly supported Vladimir Semenov, thus forcing Stanislav Derev to resign ${ }^{65}$.

Vladimir Putin's firm actions played a major role in the settlement of the most serious conflict in the history of the Karachay-Circassian Republic. The risk of a long-lasting and bloody civil war was enormous because of the surge of nationalist sentiments among the Karachays and the Circassians. The federal government was afraid of a repetition of a Chechen scenario and the possibility of implementation of the "Great Caucasus"

\footnotetext{
62 T. Muzajev, Karačaevo - Čerkesskaâ Respublika. Hronika protivostoâniâ, http:// www.igpi.ru/monitoring/1047645476/1999/0999/9.htm.

63 See I. Loriâ, Kavkazskij vybor, "Novye Izvestija”, 1.06.1999.

64 See T. Muzajev, Karačaevo - Čerkesskaâ Respublika..., op.cit.

65 Ibidem.
} 
project. The federal government's initial unwillingness to recognize the victory of Vladimir Semenov is partly explained by rumors of his alleged support for separatist ideas. However, those rumors had nothing to do with reality. The Karachay politician was loyal to Moscow. The Wahhabist threat was in fact illusive ${ }^{66}$.

Moscow's arbitration proved to be effective: the Circassian protests quickly died away. During the rule of V. Semenov the political situation in Karachay-Circassia calmed down and the risk of war between warring ethnic groups was averted. Vladimir Semenov did not support separatist tendencies, disapproved of radical Islamist tendencies, counteracted the split of the republic and maintained good relations with the government of the Russian Federation. What is more, he supported Vladimir Putin's campaign against the separatist underground in Northern Caucasus ${ }^{67}$.

\section{THE TROUBLEMAKING RECONFIGURATIONS AMONG THE RULING ELITE IN THE FIRST DECADE OF THE 21ST CENTURY}

After Vladimir Semenov's victory, the former elites centered around Vladimir Khubiev lost their power. A new hierarchy of power (vertikal' vlasti) emerged. The Karachay clans which were not allowed to participate in the ruling elites in the times of Vladimir Khubiev's rule, suddenly became the strongest in the region. The members of "the old The Karachay elite" switched to being the opposition, hoping to regain power after the next presidential election ${ }^{68}$.

The stabilization in the region was based on fragile foundations. Vladimir Semenov strived to restore order in the region and tried to be the leader of all the citizens of Karachay-Circassia, irrespectively of their

\footnotetext{
66 Islam na obszarze postradzieckim, materiał analityczny Ośrodka Studiów Wschodnich, Warszawa 2003, p. 38.

67 Ibidem.

68 See A. Sanglibaev, Ėtnopolitičeskie processy na severnom Kavkaie na sovremennom ètape. Avtoreferat doktorskoj dissertactii po politike, Stavropol 2008.
} 
ethnic origin, did not manage to get rid of his reputation as the exponent of the Karachay interests.

The Circassians who were reluctant to support the new president did not stop to protest against his rule and claim separatist demands, although they did temporarily give up violence.

The wave of national rebirth seemed to lower in comparison to the beginning of the 1990 s, but the strongest Circassian organization "Adyge Khase" was becoming ever stronger. It became the largest opposition force in the republic and a potential factor of regional destabilization.

The presidential election of 2003 once more provoked tensions in the republic. The Karachay-Circassian strongman Vladimir Semenov expected an easy victory.

To the surprise of the observers, the president of the National Bank of Karachay-Circassia, Mustafa Azret-Alievich Batdiev, became the main opponent of the incumbent president ${ }^{69}$.

Vladimir Semenov was the strongest candidate, he had the widespread support of the Karachay people, while the Circassians invariably disliked him. Mustafa Batdiev, who is a pure Karachay unlike Vladimir Semenov, managed to earn significant popularity among the Circassians and the Abazins: he managed to convince them that as the leader of the republic he would be a representative of the Adyghe nations ${ }^{70}$.

The presidential election of August 17 2003 triggered a new wave of nationalism.

From-time-immemorial-lasting animosities between the Karachays and the Circassians exploded again, although this time the scale of violence did not equal that of the political crisis of 1999 (the situation in the Caucasus during the presidency of Vladimir Putin was incomparably more stable than in the time of the decline of Boris Yeltsin). Mainly internal ethnic conflicts manifested during the election - the "old" Karachay elite of the Khubiev era concentrated around Mustafa Batdiev and issued a challenge to the "new" Karachay elite, identified with Vladimir Semenov's collaborators. What is more, Mustafa Batdiev made use of Circassian and

69 See Batdyev Mustafa Azret-Alevič, http://www.pfrf.ru/ot_karcher/leadership/

70 K. Kazenin, Tihie konflikty na Severnom Kavkaze, Moskva 2009, p. 130. 
Abazin clans potential; those had no Chance to take power in the republic due to their small number ${ }^{71}$.

The election campaign was full of aggression. The candidates accused each other of supporting the forces hostile to the Karachay-Circassia and the Russian Federation.

Despite a fierce campaign, according to the calculations of the representatives of his electoral staff, Vladimir Semenov could be confident of victory. And yet, it was Mustafa Batdiev who was the unexpected winner of the first round. The bank president got $41,67 \%$, while the incumbent president $-39,92 \%{ }^{72}$.

The small difference between Semenov and Batdiev results exacerbated the political conflict. Both candidates accused each other of bribery, intimidation of voters and manipulations (mainly organization of so-called "multiple voting" $)^{73}$. The mutual accusations of the candidates regarding connections with Wahhabi extremists became a kind of peculiar political tradition of the republic ${ }^{74}$.

The second round took place on August $31^{\text {st }}$ 2003. Its winner was Mustafa Batdiev, who got $47,97 \%$ of the votes. Vladimir Semenov got $46,41 \%$ of the votes ${ }^{75}$. His protests were dismissed. Mustafa Batdiev became the president of the Karachay-Circassian Republic. His victory meant the retaliation of the "old" The Karachay elite of the Khubiev era which was marginalized during the presidency of Vladimir Semenov ${ }^{76}$.

The new president was elected thanks to mass support among the Adyghe nations. Just after his electoral victory, he was more tolerant towards the Circassian nationalist movement. In the times of the Batdiev

71 See A. Sanglibaev, Ėtnopolitičeskie processy..., op.cit.

72 See Prezidentske vybory v Karačaevo - Čerkesii vyigral bankir, http://grani.ru/ Politics/Russia/Regions/m.41850.html.

73 Ibidem.

74 More about the accusations against M. Batdiev of providing financial suport to Wahhabi underground in Karachay-Circassia: http://vybory-kchr.narod.ru/files/ This kind of accusations were issued against V. Semenov starting form 1999.

75 "Moi starye soperniki našli novuû marionetku": Intervû prezidenta KaračaevoČerkesii Vladimira Semënova IA REGNUM, http://www.regnum.ru/allnews/150843.html [21.01.2012].

76 See A. Sanglibaev, Ètnopolitičeskie processy... 
presidency (who, it should be noted, always emphasized his support for the principle of unity of the republic and condemned separatism in official statements), the "Adyge Khase" movement became a major political power. The Circassian nationalists started to overtly support the idea of "Great Adyghe from the Black Sea to the Caspian Sea" and returned to the idea of inter-regional cooperation in favor of separatism.

The conflict between "the old" and "the new" Karachay elites was exacerbated after the events of October $11^{\text {th }} 2004$ when seven people were killed in the president's son-in-law Ali Kaitow's mansion (they were: the Karachay-Circassia Parliament deputy Rasul Bogatirev and six businessmen belonging to the financial elite of the republic who accompanied him $)^{77}$.

Despite many signs of federal center's dissatisfaction with the situation in the region, Mustafa Batdiev was not removed from his post. Meanwhile, the Karachay opposition gained influence ${ }^{78}$. The president's opponents were a major political power, even though they did not manage to force the president to resign prematurely.

Mustafa Batdiev's term in office ended in 2008. In December 2004, the way of selecting the leaders of the subject-states of the Russian Federation changed. The next president of The Karachay-Circassia was not to be elected in a popular vote, but to be appointed by the President of the Russian Federation and confirmed by the National Assembly of KarachayCircassia. After the tragic events of October, 2004, another nomination for Mustafa Batdiev seemed unlikely. The members of The Karachay opposition hoped that an exponent of their interests would get the nomination ${ }^{79}$.

77 See Muhin, M. Bondarenko, Vladimir Semënov...; K. Kazenin, Tihie konflikty..., p. 148.

78 See K. Kazenin, Tihie konflikty..., pp. 149-151.

79 Alim Uzdenov, the deputy to the State Duma from the "United Russia" party was considered to be the most probable candidate. He had a reputation of a politician who is loyal to Moscow and in the same time not connected with any of the Karachay clans. See: Dmitrij Medvedev vnës kandidaturu Borisa Èbzeeva na post glavy Karačaevo Čerkesii, http://www.kavkaz-uzel.ru/articles/139794/. 
Things turned out differently. On July $30^{\text {th }} 2008$, Boris Safarovivh Ebzeev, an ex-Constitution Court judge of Karachay origin, became the presidential nominee. Boris Ebzeev's nomination was a surprise - he was perceived as a scholar rather than a political actor. Boris Ebzeev, an eminent specialist in constitutional law, had a reputation of a liberal intellectual, a human right advocate and a critic of the ruling elites' abuses.

The Moscow elites had significant hopes for Boris Ebzeev, especially that the level of corruption had long before surpassed any acceptable limits. Many pathological consequences of the clan mechanisms and the brutalization of customs were pointed out ${ }^{80}$. Boris Ebzeev became a protagonist of a counter-corruption campaign ${ }^{81}$. Circassian activists also trusted the president who was not entangled in the animosities between Karachay clans. They hoped he might put an end to the Karachay supremacy in the republic ${ }^{82}$. However, the Circassian politicians were very soon disappointed. Boris Ebzeev distanced himself from the Circassian nationalist activists and even dismissed some of the officials of Circassian origin ${ }^{83}$.

The new president pursued a goal of modernization of the state that he understood as reducing the role of the ethnic factor in politics. Boris Ebzeev perceived ethnic and clan mechanisms as the main source of pathologies in the Karachay-Circassian social and political life ${ }^{84}$. Ignoring the importance of the national issues by Boris Ebzeev sometimes seemed even ostentatious.

The president assessed the situation in the republic using extremely harsh words. He claimed that the lack of terrorist acts in the Republic is nothing compared to the dramatic levels of crime and corruption ${ }^{85}$. It is possible, however, that the surge of ethnic separatism, especially among

\footnotetext{
80 See Dmitrij Medvedev vnës kandidaturu...

81 See Žiteli Karačaevo - Čerkesii ždut reform ot novogo prezidenta respubliki, http:// www.kavkaz-uzel.ru/articles/141785/.

82 See K. Kazenin, Tihie konfliky..., p. 136.

83 See Čerkesov: Èbzeev narušil nacional’nyj balans Karačaevo - Čerkesii, http://virtcircassia.ucoz.com/news/2008-12-04-684.

84 See O. Allenova, Vsë idët po klanu, “Ogonëk”, 2012, No. 9.

85 See Ėbzeev: V Karačaevo-Čerkesii gromkie priestupleniâ ostaûtsâ nieraskrytymi, http://karabakh.kavkaz-uzel.ru/articles/148352.
} 
the Circassians, was an even more serious problem ${ }^{86}$. The already powerful "Adyge Khase" movement made its influence even broader than before during Ebzeev's presidency.

On February $26^{\text {th }} 2011$, Boris Ebzeev was dismissed by Dmitri Medve$\operatorname{dev}^{87}$. According to the official version, he resigned. According to the commentators, the Kremlin for a long time made no secret of its dissatisfaction with the results of Boris Ebzeev's policy. Nobody questioned the merits, the competence and the personal integrity of the outgoing president. However, Boris Ebzeev did not fulfill the hopes of the Moscow ruling elites put in him: firstly, he did not manage significant improvements in the social and economic situation in the region. The main cause of the dismissal, however, were the ethnic policy errors. The commitment to the principles of meritocracy often took the form of ignoring the role of the ethnic issues. Boris Ebzeev wanted the ethnic and clan factor to lose its main role in the political life of the Republic. However, the decisions of the president paradoxically had the opposite effect - they fostered the exacerbation of the ethnic animosities ${ }^{88}$.

On February $26^{\text {th }}$ 2011, Rashid Borispevich Temrezov, a Karachay businessman born in Cherkessk in 1976 who did not belong to the republican ruling elites before, became the next president ${ }^{89}$. In the opinion of the commentators, Rashid Temrezov appointment means a return to power of the so-called "old" The Karachay elites, connected to the former president, Mustafa Batdiev ${ }^{90}$. The new president abandoned the policy of "modernization", which was expressed in attempts to diminish the role of

\footnotetext{
86 See Parlament Karačaevo-Čerkesii vnov nie smog izbrat'senatora, http://karabakh. kavkaz-uzel.ru/articles/156667/.

87 B. Ebzeev was the first head of the subject of Russian Federation to be both appointed and dismissed by D. Medvedev.

${ }^{88}$ See "Ėti gady menâ pobedili". Zagadočnaâ a otstavka glavy Karačaevo-Čerkesii, "Moskovskij Komsomolec" 28.02.2011.

89 See Biografiâ glavy Karačaevo-Čerkesskoj Respubliki, http://www.kchr.info/biography.html, Temrezov Rašid Borispevič.

90 See O. Allenova, Wsè idèt po klanu; F. Tlisova, Prezident i klany, http://www. voanews.com/russian/news/Karachayevo-Cherkessiya-president-02-26-2011-11698 4808.html, Temiezov Rašid Borispovič http://www.kavkaz-uzel.ru/articles/181738.
} 
the ethnic factor in politics. Rashid Temrezov's presidency had not been going for long enough, so one could already formulate its clear evaluation.

In contrast to the north-east Caucasus republics, religion plays a minor role in the political life of Karachay-Circassia. The ideas of radical political Islam have few supporters. The rivalry and neo-tribal mechanisms ${ }^{91}$ among the ethnic elites remains the most important threat to political stability and the internal security of the Karachay-Circassian Republic.

\section{CONCLUDING REMARKS}

The period of conquest and sovietization left a heavy stigma on the contemporary situation in Karachay-Circassia. The problems related with ethnic politics, deportations, power and the mechanisms of recruitment and the functioning of the political elites that had their source in those times, manifest themselves until today in different and modifying incarnations. They reveal the weaknesses of the political model of a two-nationality republic. According to the creators of this model, both title nations should balance each other's influences in the republic, not letting any of them achieve a hegemony position. In the 1990s it turned out that such a balance is unachievable in Karachay-Circassia. The Karachay clans dominated the power structures in the Republic, while the influence of the Adyghe people diminished and the Slavic population was completely marginalized.

The "constitution pact" concluded by the elites in 1999 did not settle the ethno-political problems in the republic. The peculiar clash of axiology and civic state norms with the ideology of national state resulted in an ethnocracy. The constitution was a continuation of the numerous mistakes having its roots in Soviet times. Its numerous amendments created yet another battleground between ethnic elites, as well as among specific elites as regards the issues concerning relations with the federal elites, the integrity or division of the Republic, as well as the mechanisms of recruitment to the republican authorities structure.

91 See R. Bäcker, Podstawowe kategorie..., op.cit., p. 67. 
Relations between both title ethnic groups Karachay-Circassia are incredibly complex, full of mutual prejudice, mistrust and often also hostility. So far, the political elites of Karachay-Circassia have managed to avoid civil war which could become a spark to ignite tragic ethnic conflict involving the entire North Caucasus and the south of the Russian Federation. In the first decade of the $21^{\text {st }}$ century, the tension in relations among the political elites oscillated between the short terms of relative stability and times of conflict.

How to avoid fights between the nationalities, maintain political stability and start the process of national consolidation in Karachay-Circassia? Every president of the Russian Federation will have to face this challenge. The price of omissions and passiveness is too high. Not only the citizens of Karachay-Circassia would pay for it, but also all the other nations of the region, because of the eminent role of the Republic in the geopolitical structure of the Caucasus. The ethnical dimension of politics plays a key role in the process of solving the Republic's problems. The question of the political model of the Republic is not any less important. It does not necessarily have to be federal. In its political reconfiguration the nations' right to self-determination should play an important role. The experiment of president Boris Ebzeev who denied any role to the ethnic factor and advocated liberal modernization solutions ended as a fiasco.

The application of policy of balance between the ambitions of every ethnic group, as well as the respect for the role of local traditions and laws. However, one can hardly expect such effects from the partial reforms announced by the Russian federal authorities at the beginning of 2012 and concerning ethnic policy, including the selection and functioning of the elites in multiethnic republics. 